\title{
Application of Stem Cells in Stroke: A Multifactorial Approach
}

\author{
Manisha Singh 1,2, Pranav K. Pandey³, Ashu Bhasin ${ }^{4}$, M. V. Padma ${ }^{4}$ and Sujata Mohanty ${ }^{1 *}$ \\ ${ }^{1}$ Stem Cell Facility (DBT-Centre of Excellence for Stem Cell Research), All India Institute of Medical Sciences, New Delhi, \\ India, ${ }^{2}$ Dr. Solomon H. Snyder Department of Neurosciences, Johns Hopkins University, Baltimore, MD, United States, \\ ${ }^{3}$ Dr. R.P. Centre for Ophthalmic Sciences, All India Institute of Medical Sciences, New Delhi, India, ${ }^{4}$ Department \\ of Neurosciences, All India Institute of Medical Sciences, New Delhi, India
}

\section{OPEN ACCESS}

Edited by:

Syed Shadab Raza,

ERA's Lucknow Medical College, India

Reviewed by:

Niyaz Ahmad,

Imam Abdulrahman Bin Faisal

University, Saudi Arabia

Mohd Farooq Shaikh,

Monash University, Malaysia

Saif Ahmad,

Barrow Neurological Institute (BNI),

United States

*Correspondence:

Sujata Mohanty

drmohantysujata@gmail.com

Specialty section:

This article was submitted to

Neural Technology,

a section of the journal

Frontiers in Neuroscience

Received: 04 February 2020

Accepted: 16 April 2020

Published: 09 June 2020

Citation:

Singh M, Pandey PK, Bhasin A, Padma MV and Mohanty S (2020) Application of Stem Cells in Stroke:

A Multifactorial Approach.

Front. Neurosci. 14:473.

doi: 10.3389/fnins.2020.00473
Stroke has a debilitating effect on the human body and a serious negative effect on society, with a global incidence of one in every six people. According to the World Health Organization, 15 million people suffer stroke worldwide each year. Of these, 5 million die and another 5 million are permanently disabled. Motor and cognitive deficits like hemiparesis, paralysis, chronic pain, and psychomotor and behavioral symptoms can persist long term and prevent the patient from fully reintegrating into society, therefore continuing to add to the costly healthcare burden of stroke. Regenerative medicine using stem cells seems to be a panacea for sequelae after stroke. Stem cellbased therapy aids neuro-regeneration and neuroprotection for neurological recovery in patients. However, the use of stem cells as a therapy in stroke patients still needs a lot of research at both basic and translational levels. As well as the mode of action of stem cells in reversing the symptoms not being clear, there are several clinical parameters that need to be addressed before establishing stem cell therapy in stroke, such as the type of stem cells to be administered, the number of stem cells, the timing of dosage, whether dose-boosters are required, the route of administration, etc. There are upcoming prospects of cell-free therapy also by using exosomes derived from stem cells. There are several ongoing pre-clinical studies aiming to answer these questions. Despite still being in the development stage, stem cell therapy holds great potential for neurological rehabilitation in patients suffering from stroke.

Keywords: stroke, stem cells, mesenchymal stem cells, clinical trials, pre-clinical studies

\section{INTRODUCTION}

Stroke is one of the leading causes of chronic disability and mortality, with 102 million disabilityadjusted life years lost annually (Steven, 2008). The Global Burden of Disease, Injuries, and Risk Factors Study (GBD 2015) reported a shift from communicable diseases toward non-communicable diseases like cerebrovascular events. While the incidence of stroke is decreasing in the developed world, it has peaked in low- and middle-income countries like India due to demographic transition and rapid shifts in the socioeconomic milieu (Thomson, 1998). The estimated adjusted prevalence rate of stroke is reported to have a range of $84-262 / 100,000$ in rural and 334-424/100,000 in urban India (Wichterle et al., 2002; Nagai et al., 2010).

The only neuroprotective agent developed for stroke in clinical use is recombinant tissue plasminogen activator (rtPA), which is employed for thrombolysis and has a therapeutic window of 
merely 3-4.5 h. There is thus a compelling need to develop therapeutic agents that extend beyond the first few hours after onset of stroke. This requires a paradigm shift to the usage of new strategies from neuroprotection to neuro-restoration that treat the injured or compromised brain tissue.

The majority of stroke survivors are left with some degree of disability, particularly upper limb dysfunction, despite several neurorehabilitation therapies. Physical therapy incorporating exercises, motor learning principles, motor cortex stimulation (using rTMS, TDCS), and assistive technologies aid the restoration of functional movements (Tae-Hoon and YoonSeok, 2012). The emergence of regenerative medicine has fueled interest across readers and clinicians to study its potential. Over the last decade, an enormous amount of work has been done exploring the potential of a variety of cells like adult stem cells, umbilical cord blood, and cells from adipose tissue and skin.

\section{Pattern of Stroke Recovery}

The recovery after stroke has been explained as a rich cascade of events encompassing cellular, molecular, genetic, demographic, and behavioral components. Such factors have been proven as covariates in therapeutic trials of restorative agents with a sound neurobiological basis. Advances in functional neuroimaging and brain mapping methods have provided a valuable parallel system of data collection for stroke recovery in humans. The recovery in a stroke-affected individual will largely depend on the size of lesion, the internal milieu of the brain injury, and the age and comorbid status of the patient. In general, the first epoch encompasses the initial hours after a stroke, when rapid change occurs in blood flow, edema, pro-inflammatory mechanisms. A second epoch is related to spontaneous behavioral recovery, which begins a few days after stroke onset and lasts several weeks. During this epoch, the brain is galvanized to initiate repair, as endogenous repair-related events reaching peak levels, suggesting a golden period for initiating exogenous restorative therapies. A third epoch begins weeks to months after stroke, when spontaneous behavioral gains have generally reached a plateau, and this stable state is responsive to many restorative interventions (Steven, 2008).

\section{Mechanisms of Action of Stem Cells in Neural Repair}

Stem cells have the capacity to differentiate into all types of cells. Exogenously administered cells appear to stimulate endogenous reparative processes and do not replace injured cerebral tissue. It was once thought that intravenously administered cells would home in on the injured site and replace the dead neurons, but the current ideology for the use of these cells holds that these cells release many trophic factors like VEGF, IGF, BDNF, and tissue growth factors that stimulate brain plasticity and recovery mechanisms. Upregulation of growth factors, prevention of ongoing cell death, and enhancement of synaptic connectivity between the host and graft are some of the common pathways through which intravenous stem cells work as "chaperones." Regarding the timing of transplantation, preclinical studies have shown that cell therapy increases functional recovery after acute, sub-acute, and chronic stroke (Bliss et al., 2010), but few studies have compared different time windows, with differing results according to the model system and cell type studied. All of the possible modes of action of stem cells have been described in Figure 1.

\section{TRANSLATIONAL APPROACH FOR THE DEVELOPMENT OF REGENERATIVE MEDICINE IN BRAIN STROKE}

The unique capacity of stem cells of self-renewal and differentiation has been exploited to devise cell-based therapy for various neurodegenerative diseases, including brain stroke. There have been several studies, which will be discussed in the upcoming paragraphs, that report the use of stem cells in the treatment of various diseases. These studies have used stem cells of various kinds, such as adult stem cells (mesenchymal stem cells and neural stem cells), embryonic stem cells, and the latest kind, induced pluripotent stem cells. Apart from using different types of stem cells, scientists have also reported distinctive modes of action to support their study outcomes. Besides these variable points, there are other considerations like the dosage of stem cells, mode of administration of stem cells, and whether or not booster doses are required, depending upon the magnitude of the disease. Various groups have attempted to answer these vital questions through their research.

Ischemic stroke causes severe damage to the brain cells by destroying the heterogeneous cell population and neuronal connections along with vascular systems. The regenerative potential of several types of stem cells like embryonic stem cells, neural stem cells, adult stem cells (Mesenchymal stem cells), and induced pluripotent stem cells have been assessed for treating stroke. The outcomes and observations in these studies are not consistent. Most of the studies have only commented on the homing, survival, proliferation, and differentiation of stem cells on the site and their limited neuro-restorative ability. Embryonic stem cells (ESCs) are pluripotent cells derived from the inner cell mass of the blastocyst. There have been a few studies where engraftment of murine ESCs in mouse models of ischemia has led to the restoration of behavioral deficits, synaptic connections, and damaged neurons (Thomson, 1998; Wichterle et al., 2002; Nagai et al., 2010). However, the use of ESCs in the clinical setting is argued against by many other groups due to their immunogenic nature and teratoma-forming tendency (Fong et al., 2010; Kawai et al., 2010; Ghosh et al., 2011). Hence, scientists are now trying to establish the neuro-restorative ability of other stem cell types. Neural stem cells (NSCs) are theoretically the most appropriate cell candidates for neuro-restoration as they belong to the same tissue source and have a natural tendency to differentiate into neuronal cells. NSCs are multipotent cells that are generally found in the subgranular zone of the dentate gyrus of the hippocampus (Toda et al., 2001). Engraftment of NSCs has been reported to lead to the reformation of synaptic connections and improvement in the electrophysiological properties of mature neurons in the damaged brain (Polezhaev and Alexandrova, 1984; Polezhaev et al., 1985; Cho et al., 2002; Oki et al., 2012). They do 


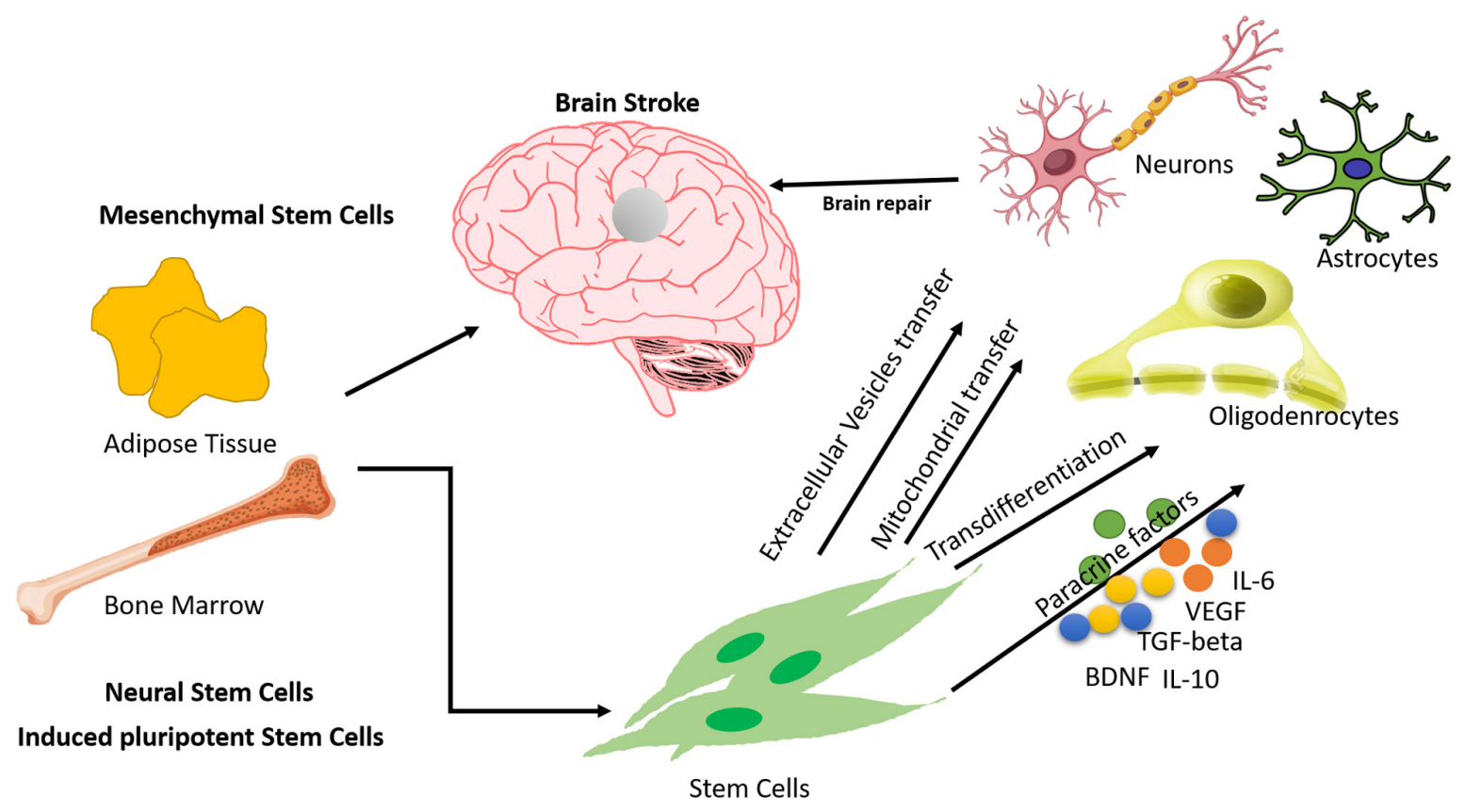

FIGURE 1 | Mechanisms of action of Mesenchymal Stem Cells in treating stroke.

so by improving the extracellular microenvironment and hence encouraging neuronal circuit plasticity (Ourednik et al., 2002; Lee et al., 2007; Redmond et al., 2007; Jeyakumar et al., 2009). NSCs restore neuronal functions as they secrete several neurotrophic factors like BDNF and VEGF, which help in maintaining the health, generation, proliferation, and survival of the neurons, along with the maintenance of ECM (Emanueli et al., 2003; Jung et al., 2008; Lee H. J. et al., 2010; Smith et al., 2012). VEGF specifically helps in angiogenesis and vascular restoration of the blood vessels damaged due to ischemia (Song et al., 2015; Ryu et al., 2016). CNTF, GDNF, NGF, and other such factors secreted by NSCs also play vital roles in the protection, maintenance, and proliferation of neural cells (Abe, 2000).

Another type of cells with amazing neuro-restorative potential and that have several other desirable properties, like being immunologically naive, easy to extract and maintain and expand in vitro, and not having associated ethical concerns, are mesenchymal stem cells (MSCs) (Baksh et al., 2007; Uccelli et al., 2008; Russell et al., 2018). MSCs are multipotent stem cells that have their niche in body tissues like bone marrow, adipose tissue, umbilical cord, umbilical cord blood, dental pulp, etc (Uccelli et al., 2008; Singh et al., 2017; Russell et al., 2018). Extracting MSCs from these tissues is a very well-established and easy process and has been very widely used in various clinical trials (Nandy et al., 2014; Singh et al., 2017). MSCs lead to neurorestoration by one or more modes of action such as the release of paracrine factors, cell replacement, mitochondrial transfer, etc. MSCs also have an angiogenic effect. They have been reported to induce angiogenesis by the release of vascular endothelial growth factor (VEGF) (Li et al., 2000, 2001; Chen et al., 2003; Shen et al., 2007). The only issue to be considered for using bone marrowderived MSCs is the surgical intervention to obtain the bone marrow. Adipose tissue-derived MSCs have proved to be equally effective in neuro-regeneration, with the added advantages of being easily accessible and more abundant (Yang et al., 2012; Moore and Abrahamse, 2014; Singh et al., 2017). Adipose tissuederived MSCs have been known to play a protective role through the release of extracellular vesicles. There are studies reporting the safety and efficacy of extracellular vesicles derived from adipose tissue-derived MSCs (Ra et al., 2011; Zhang Y. et al., 2015; Chen et al., 2016; Bang and Kim, 2019). However, more detailed studies are required to establish MSCs as therapeutic agents.

Another type of stem cell that has been explored for its translational value recently is the induced pluripotent stem cell (iPSC). There has been a boom in research into iPSCs after the groundbreaking discovery by Takahashi and Yamanaka (2006). iPSCs have the edge over other types of stem cells due to being non-immunogenic, easy to access, and non-interventional and not giving rise to ethical concerns. However, their generation is still an unresolved issue, as the reprogramming efficiency is still very low. Additionally, some studies have reported the formation of teratoma in the mouse brain, which implies that the tumorigenicity of iPSCs needs to be addressed and resolved before taking them into the clinical setting. iPSCs seem to be formidable stem cells for tissue regeneration (Israel et al., 2012; Fernández-Susavila et al., 2019).

\section{Bioactive Constituents in Brain Stroke: Combination Therapy}

The use of complementary and alternative medicine along with stem cell therapy also plays an important role in the recovery of brain stroke patients. During the stroke episode, most of the pro-inflammatory cytokines are involved, and many polyphenol compounds extracted from different parts of medicinal plants 
have been shown to protect against cerebral ischemia in preclinical models. Glycrrhizin extracted from the licorice root, Glycrrhiza glabra, protected against the rat brain injury induced by stroke. Intraperitoneal administration of Glycrrhizin pre- and post-stroke helped inhibit the infarction by ameliorating the IFN- $\gamma$ mediated T-cell activity, which was partially modulated by high mobility group box-1 (Xiong et al., 2016). The use of intravenous administration of recombinant plasminogen tissue activator (rtPA) was approved half a decade ago, but the limitations to rtPA treatment include a narrow therapeutic window of $4.5 \mathrm{~h}$ post-stroke and a high risk for hemorrhagic transformations. MSC transplantation in brain stroke patients is an existing approach, but inflammation has sometimes been observed in MSCs due to oxygen glucose deprivation during treatment. One study showed that a nano-formulation of gelatin-coated polycaprolactone loaded with naringenin, a strong anti-inflammatory, protected the MSCs against oxygen glucose deprivation-induced inflammation and also reduced the levels of pro-inflammatory cytokines (TNF- $\alpha$, IFN- $\gamma$, and IL$\beta$ ) and of the anti-inflammatory biomarkers COX-2, iNOS, and MPO (Ahmad et al., 2019). The active compound Eugenol, isolated from Acorus gramineus, was tested in a cerebral ischemia perfusion rat model. Pre-treatment with Eugenol in the rat model showed that it was prompt in attenuating cerebral ischemic injury by inducing autophagy via the AMPK/mTOR/P70S6K signaling pathway. In another study, the neuroprotective effect of quercetin was demonstrated in mice, and the findings suggested that the quercetin helped reduce apoptosis in the focal cerebral ischemia rat brain and that the mechanism may be related to the activation of the PI3K/Akt signaling pathway (Yao et al., 2012). The intragastric administration of berberin and glycyrrhizin showed neuroprotective effects in mice subjected to transient middle cerebral artery occlusion. The co-administration of glycyrrhizin and berberin showed more potent suppression on the HMGB1/TLR4/NF-kB pathway in comparison to treatment with either alone. The results of the study suggested that the administration of these compounds protects the brain from ischemia-reperfusion injury and that the mechanism may rely on their anti-inflammatory effects and, moreover, also by suppressing the activation of the HMGB1/TLR4/NF-kB signaling pathway (Zhu et al., 2018). Medicinal plants contain several important bioactive constituents that help in several modalities. Numerous pre-clinical studies have been performed using plantderived products that help modulate the proliferation and differentiation of MSCs, as well as being useful in the field of biomaterials. Therefore, the new combination therapy of phytochemicals along with stem cell therapy may become a new perspective in stem cell-based neuro-regeneration.

\section{PRE-CLINICAL STUDIES WITH STEM CELLS IN BRAIN STROKE}

The experimental evidence of the benefits of stem cells in treating stroke has been provided over the course of several years (Abe, 2000; Mays et al., 2010). The usefulness of various types of stem cells has been proclaimed in various neurological diseases, along with their safety and efficacy at both pre-clinical and clinical levels. The pre-clinical validation of stem cells in treating stroke has been instrumental. Various study groups have validated the use of stem cells in terms of various parameters such as type of stem cells, number/dose of stem cells, mode of administration, homing and tracking of stem cells, and safety and efficacy of stem cells (Zheng et al., 2018; Borlongan, 2019).

The most commonly used and most widely explored stem cells in the treatment of stroke are MSCs. Among the various tissue sources of MSCs, the most common and widely explored are bone marrow and adipose tissue, with bone marrow being the oldest of all (Andrews et al., 2008; Xin et al., 2013; Zhang et al., 2014; Zhang Y. et al., 2015). However, neural stem cells and bone marrowderived mononuclear stem cells have also been explored (Taguchi et al., 2004; Darsalia et al., 2007; Takahashi et al., 2008). In most of the pre-clinical studies, autologous bone marrow-derived MSCs have been used (Zhang et al., 2006; Khalili et al., 2012; Otero et al., 2012; Bao et al., 2013; Vaquero et al., 2013) to investigate the various aspects of stem cell transplantation in stroke. Several other studies report the use of MSCs from other tissue sources, like adipose tissue, umbilical cord, placenta, etc (Yang et al., 2012; Zhang Q. et al., 2015; Xie et al., 2016). MSCs are characterized for transplantation based on surface marker profiling, which includes the presence of markers like CD29, CD44, CD73, CD90, and CD105 and the absence of CD34/45, CD14, and HLA class II. Other critical factors that need to be considered for preclinical studies are the number/dose of cells to be administered and the mode of administration. Transplantations of MSCs range from $1 \times 10^{6}$ to $8 \times 10^{6}$ cells and are accomplished through different modes, including intravenous, intranasal, and intraarterial (Chen et al., 2001; Shyu et al., 2006; Zhang et al., 2006; Yang et al., 2012; Ma et al., 2016; Rodríguez-Frutos et al., 2016; Borlongan, 2019). While there is evidence that the transplanted MSCs have homed and differentiated into neurons, astrocytes, and oligodendrocytes upon administration through intravenous, intranasal, and intracerebral modes, there are doubts on the migration of MSCs in the brain by the intravenous mode (Díez-Tejedor et al., 2014). Also, there are mixed reports on whether the transplantation of coaxed and naive stem cells can achieve the desired outcome in terms of functional recovery, BBB function, increased angiogenesis and vasculogenesis, and tissue regeneration (Laso-García et al., 2019; Turnbull et al., 2019). More detailed studies need to be done to establish a definitive stem cell therapy regime for stroke.

\section{CLINICAL TRIALS OF REGENERATIVE MEDICINE IN BRAIN STROKE}

Cerebrovascular strokes can cause morbidity and mortality and induce long-term disability that affects quality of life. Stroke is associated with neuroinflammation, which plays a key role in the pathophysiology of cerebrovascular accidents of different types. We performed a rigorous search of a database on clinical studies with stroke and found more than 56 clinical trials on the use of regenerative medicine (autologous or allogeneic) for cerebrovascular stroke. Most of them used mesenchymal 
stem cells, adipose tissue, bone marrow-derived cells, and spinal cord and umbilical cord cells. Table 1 presents a few clinical trials involving stem cell therapy (autologous and allogeneic), giving their study design, dose, route of administration, and outcomes. Our experience with regenerative medicine in stroke emphasizes the safety and tolerance of cells, whereas efficacy still needs to be addressed. More recovery in clinical and functional patterns was observed in patients administered with autologous bone marrow-derived cells than in the group with physiotherapy alone. We also tried to elucidate correlations between functional MRI and outcome after stroke, with increased activation in premotor and primary motor areas (PM and SMA), and contralesional M1 over activation. Our present randomized controlled trial studying the paracrine effects of autologous mononuclear stem cells in interim showed increased VEGF and BDNF post-treatment in all stroke patients, suggesting endogenous recovery after restorative therapies like stem cells and a structured neuro-rehabilitation regime. To counter the progression of the cerebral vascular disease post-stroke and repair the damage induced in different regions of the brain, various clinical trials with different stem cells like mesenchymal stem cells, adipose tissue-derived stem cells, and bone marrow mononuclear stem cells are ongoing (Table 1) that investigate potential efficacy and safety, without the occurrence of any adverse or severely adverse events.

An open-labeled observer-blind clinical trial was conducted to evaluate the long-term safety and efficacy of autologous MSCs. Post-transplantation with MSCs, clinical improvement in patients was observed in the MSC-treated patient group, which was associated with the serum level of stromal cell-derived factor-1 and the degree of involvement of the sub-ventricular region of the lateral ventricle. No serious adverse effects were observed during long-term follow up of patients. The occurrence of comorbidities was similar in comparison to the control group (Lee J. S. et al., 2010). In another single-blind controlled phase I/II trial, patients with middle cerebral artery stroke were enrolled in the study. Autologous bone marrow mononuclear cells (BMMNCs) were injected 5-9 days post-stroke. A higher plasma $\beta$-nerve growth factor level was observed post-injection, and no adverse events were observed for 6 months apart from two patients in whom partial seizures were observed at 3 months of follow up. The study result suggested that intra-arterial administration of BM-MNCs is safe and feasible (Moniche et al., 2012). A non-randomized observational controlled study with autologous bone marrow mononuclear cells in chronic ischemic stroke showed better efficacy and did not observe any adverse effects or neurological abnormalities during long-term follow up of patients (Bhasin et al., 2012). Intravenous administration of autologous BM-MSCs was also shown to have better safety in a randomized, phase II, multicentric trial group in patients with subacute ischemic stroke (Prasad et al., 2014). On the basis of the findings of pre-clinical studies with peripheral blood stem cells (PBSCs), randomized single-blind controlled studies were conducted in patients with middle cerebral artery infarction. Patients were enrolled as per the inclusion criteria of the study and received subcutaneous G-CSF injection for 5 consecutive days prior to stereotaxic implantation of immune-sorted PBSCs.
No adverse events were observed during the study procedure or the follow up of the study. Clinical outcomes of the PBSC-treated and control groups were observed in terms of changes in NIHSS, ESS, EMS, and mRS from baseline to 12 months. Moreover, this study also provided important evidence on the efficacy of PBSCs in improving stroke-related motor deficits, the reconstruction of injured CST, and the rebuilding of electrophysiology activity from the brain to the limbs (Chen et al., 2014). Intravenous administration of allogeneic mesenchymal stem cells from adipose tissue in a phase II randomized, double-blind, placebo controlled single-center pilot clinical trial in patients 2 weeks post-acute stroke showed better efficacy without the occurrence of adverse events. Moreover, the use of allogenic MSCs could be an alternative therapy for the treatment of stroke because it has been demonstrated that they lack class II HLA antigens (Díez-Tejedor et al., 2014). Another study (Bhasin et al., 2016) reported the paracrine mechanism of bone marrow-derived mononuclear cells in chronic ichemic stroke patients. CD34+ was counted in BM-MNCs for each and every patient. Intravenously administered BM-MNCs secrete glial cell-derived neurotrophic factor and BDNF, IGF-1, and VGEF, which may protect against the dysfunction of motor neurons. The trial results suggested that the administration of BM-MNCs is safe and feasible for stroke patients. In another phase I, open-label, prospective clinical trial, patients with acute ischemic stroke received a single i.v. infusion of allogeneic human umbilical cord blood cells within a window of 3-10 days. Post-UCB infusion, graft-vs.-host disease, infection, and hypersensitivity were analyzed at patient follow up visits at 3, 6, and 12 months. Adverse events and severe adverse events (AE/SAE) in the patients that were directly or indirectly related to the investigational treatment were reported (Laskowitz et al., 2018).

A single-arm, phase I clinical trial study of autologous bone marrow mononuclear cells for acute ischemic stroke showed a promising new investigational modality that may help widen the therapeutic window for patients with ischemic stroke. AEs/SAEs were observed post-transplantation, some of which may have been associated with the intervention but others of which may not have (Vahidy et al., 2019). In another single-site phase I study, the feasibility and safety of NSI-566 primary adherent neural cells derived from a single human fetal spinal cord were observed. Three different doses were investigated in a cohort study of patients, and it was shown that the transplantation of human spinal cord-derived neural stem cells into the periinfarct area of stable stroke patients is beneficial. The mechanism potentially behind it is that the stem cell-derived tissue is largely composed of interneurons and glial cells, and these promote regeneration and act as bridges between regenerating neuronal fibers (Zhang et al., 2019). A phase I/II preliminary safety and efficacy study of allogenic MSCs in chronic stroke patients showed the dose tolerability to be 1.5 million $/ \mathrm{kg}$ body weight in phase I and phase II study. The primary outcome of intravenous administration of allogenic MSCs in patients was measured for 1 year, and secondary outcomes were measured in terms of behavioral changes. AEs/SAEs were observed in 13 patients that were probably not related to the intervention, and two mild AEs related to the study intervention 
TABLE 1 | List of Clinical trials using Stem cells in treating stroke.

\begin{tabular}{|c|c|c|c|c|c|c|c|c|c|c|c|}
\hline $\begin{array}{l}\text { Country } \\
\text { and year }\end{array}$ & Study design & Sample size & Stroke type & Cells from & $\begin{array}{l}\text { Interventional } \\
\text { type }\end{array}$ & $\begin{array}{l}\text { Route of } \\
\text { administration }\end{array}$ & Dose & $\begin{array}{l}\text { Time point from } \\
\text { onset of infusion }\end{array}$ & $\begin{array}{l}\text { Followup } \\
\text { (Months) }\end{array}$ & $\begin{array}{l}\text { Primary outcome } \\
\text { indicator }\end{array}$ & References \\
\hline $\begin{array}{l}\text { South Korea, } \\
2010\end{array}$ & $\begin{array}{l}\text { Open-label, } \\
\text { observer-blinded } \\
\text { clinical trial }\end{array}$ & $16 / 36$ & Acute & $\begin{array}{l}\text { Posterior iliac } \\
\text { crest }\end{array}$ & $\begin{array}{l}\text { MSCs, } \\
\text { Conventional } \\
\text { Treatment }\end{array}$ & Intravenous & $50 \times 10^{6}$ & 7 days & 60 & mRS & $\begin{array}{l}\text { Lee J. S. et al., } \\
2010\end{array}$ \\
\hline Spain, 2012 & $\begin{array}{l}\text { Single-blind controlled } \\
\text { clinical trial phase } 1 / / l\end{array}$ & $10 / 10$ & Subacute & $\begin{array}{l}\text { Posterior superior } \\
\text { iliac crest }\end{array}$ & $\begin{array}{l}\text { BM-MNCs, } \\
\text { Conventional } \\
\text { Treatment }\end{array}$ & Intraarterial & $159 \times 10^{6}$ & $\begin{array}{l}\text { Mean 5-9 days post } \\
\text { occurrence of stroke }\end{array}$ & 6 & NIHSS, Bl, mRS & $\begin{array}{l}\text { Moniche et al., } \\
2012\end{array}$ \\
\hline India, 2012 & $\begin{array}{l}\text { Non-Randomized } \\
\text { controlled clinical trial }\end{array}$ & $12 / 12$ & Chronic & $\begin{array}{l}\text { Posterior superior } \\
\text { iliac crest }\end{array}$ & $\begin{array}{l}\text { BM-MNCs, } \\
\text { Conventional } \\
\text { Treatment }\end{array}$ & Intravenous & $50-60 \times 10^{6}$ & $\begin{array}{l}3 \text { months-2 years } \\
\text { post-stroke }\end{array}$ & 6 & $\mathrm{FMA}, \mathrm{BI}$ & $\begin{array}{l}\text { Bhasin et al., } \\
2012\end{array}$ \\
\hline India, 2013 & & $20 / 20$ & Chronic & $\begin{array}{l}\text { Post superior iliac } \\
\text { crest }\end{array}$ & $M N C+$ MSCs & Intravenous & $50-60 \times 10^{6}$ & $\begin{array}{l}3 \text { months-2 years } \\
\text { post-stroke }\end{array}$ & 6 & $\mathrm{BI}, \mathrm{FMA}$ & $\begin{array}{l}\text { Bhasin et al., } \\
2016\end{array}$ \\
\hline China, 2013 & & $60 / 60$ & Chronic & Umbilical cord & UC-MSCs & $\begin{array}{l}\text { Subarachnoid } \\
+ \text { Intravenous }\end{array}$ & $100 \times 10^{6}$ & $\begin{array}{l}1 \text { month and } 6 \text { years } \\
\text { post-stroke }\end{array}$ & 3 & FMA & Hu et al., 2013 \\
\hline India, 2014 & $\begin{array}{l}\text { Multicentric, phase II } \\
\text { parallel group } \\
\text { controlled clinical trial }\end{array}$ & $60 / 60$ & Subacute & $\begin{array}{l}\text { Posterior iliac } \\
\text { crest }\end{array}$ & BMSCs & $\begin{array}{l}\text { Intravenous } \\
\text { infusion }\end{array}$ & $280.5 \times 10^{6}$ & $7-30$ days & 6 & $\mathrm{NIHSS}, \mathrm{BI}$ & $\begin{array}{l}\text { Prasad et al., } \\
2014\end{array}$ \\
\hline China, 2014 & $\begin{array}{l}\text { Randomized, } \\
\text { single-blind clinical trial }\end{array}$ & $15 / 15$ & Chronic & PBSCs & PBSCs & Stereotactic & $3-8 \times 10^{6}$ & 6 month -5 years & 12 & NIHSS, mRS & Chen et al., 2014 \\
\hline China, 2014 & & $50 / 50$ & Subacute & $\begin{array}{l}\text { Lianoning blood } \\
\text { centers }\end{array}$ & $\begin{array}{l}\text { UC-MSCs, } \\
\text { Conventional } \\
\text { treatment }\end{array}$ & Subarachnoid & $100 \times 10^{6}$ & $\begin{array}{l}14-30 \text { days } \\
\text { post-stroke }\end{array}$ & 3 & NIHSS,FMA & Feng et al., 2014 \\
\hline Spain, 2014 & $\begin{array}{l}\text { Phase lla, Prospective, } \\
\text { randomized, } \\
\text { double-blind, } \\
\text { placebo-controlled, } \\
\text { single-center, pilot } \\
\text { clinical trial. }\end{array}$ & $20 / 20$ & Acute & Adipose tissue & $\begin{array}{l}\text { Allogenic MSCs } \\
\text { from adipose } \\
\text { tissue }\end{array}$ & $\begin{array}{l}\text { Intravenous } \\
\text { administration }\end{array}$ & $\begin{array}{l}1 \text { million/unit/kg. } \\
\text { body weight }\end{array}$ & 2 weeks post-stroke & 24 & $\begin{array}{l}\text { mRS, NIHSS, MRI, } \\
\text { Biochemical markers }\end{array}$ & $\begin{array}{l}\text { Díez-Tejedor et al. } \\
2014\end{array}$ \\
\hline USA, 2018 & Phase I, Open label & $10 / 10$ & $\begin{array}{l}\text { Acute, } \\
\text { cortical } \\
\text { ischemic } \\
\text { stroke }\end{array}$ & $\begin{array}{l}\text { Allogenic } \\
\text { Umbilical cord }\end{array}$ & $\begin{array}{l}\text { Umbilical cord } \\
\text { blood infusion }\end{array}$ & $\begin{array}{l}\text { Intravenous } \\
\text { administration }\end{array}$ & $3.34 \times 10^{6}$ & $3-9$ days & 12 & mRS & $\begin{array}{l}\text { Laskowitz et al., } \\
2018\end{array}$ \\
\hline USA, 2019 & Phase I, Single arm- & $25 / 30$ & Acute & $\begin{array}{l}\text { Bone marrow } \\
\text { harvest } \\
\text { (autologous) }\end{array}$ & B-MNCs & $\begin{array}{l}\text { Intravenous } \\
\text { administration }\end{array}$ & 10 million cells/kg b.wt & $1-3$ days & 24 & mRS, NIHSS & Vahidy et al., 2019 \\
\hline China, 2019 & Cohort (Phase I) & 9 & $\begin{array}{l}\text { Hemiparesis } \\
\text { from ischemic } \\
\text { stroke }\end{array}$ & $\begin{array}{l}\text { Cells derived from } \\
\text { human fetal spinal } \\
\text { cord }\end{array}$ & $\begin{array}{l}\text { NSI-566, primary } \\
\text { adherent neural } \\
\text { stem cell }\end{array}$ & $\begin{array}{l}\text { Intracerebral } \\
\text { injection }\end{array}$ & $\begin{array}{l}\text { Cohort } A=1.2 \times 10^{7} \\
\text { Cohort } B=2.4 \times 10^{7} \\
\text { Cohort } C=7.2 \times 10^{7}\end{array}$ & Mean 494 days & 24 & CT, fMRI, PET, DTI & Zhang et al., 2019 \\
\hline $\begin{array}{l}\text { California, } \\
2019\end{array}$ & $\begin{array}{l}\text { Phase I/II Preliminary } \\
\text { safety and efficacy } \\
\text { studies }\end{array}$ & $\begin{array}{l}\text { Phase I } \\
(n=15) \\
\text { Phase II } \\
(n=21)\end{array}$ & Chronic & & $\begin{array}{l}\text { Allogeneic } \\
\text { Ischemia tolerant } \\
\text { MSCs }\end{array}$ & $\begin{array}{l}\text { Intravenous } \\
\text { transfusion }\end{array}$ & $\begin{array}{l}\text { Phase I (0.5, 1.0, and } 1.5 \\
\text { million/ } / \mathrm{kg} \mathrm{b.wt)} \mathrm{Phase} \mathrm{II} \\
1.5 \text { million/kg b.wt }\end{array}$ & & 12 & Bl, ECG, CT-Scan. & Levy et al., 2019 \\
\hline
\end{tabular}

mRS, Modified Rankin Score; MRI, Magnetic resonance imaging; PET, Positron emission tomography; CT, Computed tomography; NIHSS, National Institute of Health Stroke scale; BI, Barthel Index. 
were observed, urinary tract infection and intravenous site irritation. However, other mechanisms have also been shown that involve cell replacement, immunomodulatory action, and endogenous repair of brain damage post-stroke. The stem cell therapy in cerebrovascular accident depends overall upon their differentiation, inflammation, and ability to repair of endogenous processes. This regenerative medicine has emerged as an important tool in modern neurology, with potential efficacy in neurodegenerative disorder (Thwaites et al., 2012; Yu et al., 2013). After extensive findings of pre-clinical research, the clinical trials have conducted with different stem cells in stroke, in which the AEs/SAEs observed during or post transplantation may be directly or indirectly related to the intervention. The studies suggest that there must be a further continuation of pre-clinical and clinical studies of regenerative medicine in stroke patients to further elucidate the safety, efficacy, and toxicity pre and posting transplantation and their capacity to deliver potent efficacious regenerative medicine for stroke patients. Further clinical trials of regenerative medicine in cerebrovascular stroke are complete, with more results awaited.

\section{Future Prospects}

Regenerative medicine is looking increasingly more enticing as we capture more evidence from past and current clinical trials in stroke (Bhasin et al., 2016, 2017). The neurophysiology describing stem cells and their concatenated mechanisms suggests that restoration of brain function may be a realistic goal. There are several cellular labeling techniques available, including simple incubation, use of transfection agents, magnetoelectroporation, and magnetosonoporation. MR tracking with SPIOs and nanoparticles in a MCAo occlusion model of stroke has proven flawless in tracking cells but still needs clinical validation (Cromer Berman et al., 2011). To make this research a therapeutic boon in stroke, certain questions still need answers, such as the optimal cell delivery route, the initial engraftment and distribution pattern of injected cells, and how effectively injected cells migrate toward the affected sites.

\section{REFERENCES}

Abe, K. (2000). Therapeutic potential of neurotrophic factors and neural stem cells against ischemic brain injury. J. Cereb. Blood Flow Metab. 20, 1393-1408. doi: 10.1097/00004647-200010000-00001

Ahmad, A., Fauzia, E., Kumar, M., Mishra, R. K., Kumar, A., Khan, M. A., et al. (2019). Gelatin-coated polycaprolactone nanoparticle-mediated naringenin delivery rescue human mesenchymal stem cells from oxygen glucose deprivation-induced inflammatory stress. ACS Biomater. Sci. Eng. 5, 683-695. doi: 10.1021/acsbiomaterials.8b01081

Andrews, E. M., Tsai, S. Y., Johnson, S. C., Farrer, J. R., Wagner, J. P., Kopen, G. C., et al. (2008). Human adult bone marrow-derived somatic cell therapy results in functional recovery and axonal plasticity following stroke in the rat. Exp. Neurol. 211, 588-592. doi: 10.1016/j.expneurol.2008.02.027

Baksh, D., Yao, R., and Tuan, R. S. (2007). Comparison of proliferative and multilineage differentiation potential of human Mesenchymal stem cells derived from umbilical cord and bone marrow. Stem Cells 25, 1384-1392. doi: 10.1634/stemcells.2006-0709

Bang, O. Y., and Kim, E. H. (2019). Mesenchymal stem cell-derived extracellular vesicle therapy for stroke: challenges and progress. Front. Neurol. 10:211. doi: 10.3389/fneur.2019.00211
While stem cells have proven to be a great resource for treating stroke, there are still several obstacles to be conquered in the near future. A variety of stem cells with multiple parameters have been under trial for the treatment of stroke. Starting from the kinds of stem cells in use, there are pluripotent stem cells (ESCs and iPSCs), neural stem cells, and adult stem cells (MSCs from various tissues). There are ethical concerns associated with pluripotent stem cells. Additionally, NSCs have limitations in their in vitro expansion (in terms of the number of NSCs required to be transplanted). MSCs are capable of combating this concern. Another issue is immunological tolerance between the host body and transplanted stem cells. This issue can be resolved by using the patient's own cells to derive iPSCs of MSCs (as they are devoid of HLA class II). Besides these concerns, there are several other concerns, such as whether the efficiency of cell extraction, expansion, and differentiation is sufficient for transplantation, as well as the best mode of injection and optimal number of injections. While there are several challenges to bringing stem cell therapy in the mainstream of treatment for various diseases, stem cell therapy has been established for treating several degenerative and other kinds of diseases. In future, all these points of concern need to be addressed to make stem cell therapy an abiding treatment regime for stroke.

\section{AUTHOR CONTRIBUTIONS}

MS, $A B$, and PP: drafting and refining the manuscript. SM, MS, and $A B$ : critical reading of the manuscript. All of the authors have read and approved the manuscript.

\section{ACKNOWLEDGMENTS}

We thank Ms. Sonali Rawat, Ph.D. scholar, Stem Cell Facility, AIIMS, New Delhi, for helping us with the generation of the figure and graphical abstract.

Bao, X. J., Liu, F. Y., Lu, S., Han, Q., Feng, M., Wei, J. J., et al. (2013). Transplantation of FLK-1+ human bone marrow-derived mesenchymal stem cells promotes behavioral recovery and anti-inflammatory and angiogenesis effects in an intracerebral hemorrhage rat model. Int. J. Mol. Med. 31, 10871096. doi: 10.3892/ijmm.2013.1290

Bhasin, A., Kumaran, S. S., Bhatia, R., Mohanty, S., and Srivastava, M. V. P. (2017). Safety and feasibility of autologous mesenchymal stem cell transplantation in chronic stroke in Indian patients. A four-year follow up. J. Stem Cells Regen. Med. 14, 59-60.

Bhasin, A., Padma Srivastava, M. V., Mohanty, S., Vivekanandhan, S., Sharma, S., Kumaran, S., et al. (2016). Paracrine mechanisms of intravenous bone marrowderived mononuclear stem cells in chronic ischemic stroke. Cerebrovasc. Dis. Extra 6, 107-119. doi: 10.1159/000446404

Bhasin, A., Srivastava, M. V., Bhatia, R., Mohanty, S., Kumaran, S. S., and Bose, S. (2012). Autologous intravenous mononuclear stem cell therapy in chronic ischemic stroke. J. Stem Cells Regen. Med. 8, 181-189.

Bliss, T. M., Andres, R. H., and Steinberg, G. K. (2010). Addendum to "Optimizing the success of cell transplantation therapy for stroke". Neurobiol. Dis. 37, 275-283. doi: 10.1016/j.nbd.2010.03.001

Borlongan, C. V. (2019). Concise review: stem cell therapy for stroke patients: are we there yet? Stem Cells Transl. Med. 8, 983-988. doi: 10.1002/sctm.19-0076 
Chen, D. C., Lin, S. Z., Fan, J. R., Lin, C. H., Lee, W., Lin, C. C., et al. (2014). Intracerebral implantation of autologous peripheral blood stem cells in stroke patients: a randomized phase II study. Cell Transplant 23, 1599-1612. doi: 10.3727/096368914X678562

Chen, J., Li, Y., Katakowski, M., Chen, X., Wang, L., Lu, D., et al. (2003). Intravenous bone marrow stromal cell therapy reduces apoptosis and promotes endogenous cell proliferation after stroke in female rat. J. Neurosci. Res. 73, 778-786. doi: 10.1002/jnr.10691

Chen, J., Li, Y., Wang, L., Zhang, Z., Lu, D., Lu, M., et al. (2001). Therapeutic benefit of intravenous administration of bone marrow stromal cells after cerebral ischemia in rats. Stroke 32, 1005-1011. doi: 10.1161/01.STR.32.4.1005

Chen, K. H., Chen, C. H., Wallace, C. G., Yuen, C. M., Kao, G. S., Chen, Y. L., et al. (2016). Intravenous administration of xenogenic adipose-derived mesenchymal stem cells (ADMSC) and ADMSC-derived exosomes markedly reduced brain infarct volume and preserved neurological function in rat after acute ischemic stroke. Oncotarget 7, 74537-74556. doi: 10.18632/oncotarget.12902

Cho, T., Bae, J. H., Choi, H. B., Kim, S. S., McLarnon, J. G., Suh-Kim, H., et al. (2002). Human neural stem cells: electrophysiological properties of voltage-gated ion channels. Neuroreport 13, 1447-1452. doi: 10.1097/00001756200208070-00020

Cromer Berman, S. M., Walczak, P., and Bulte, J. W. M. (2011). Tracking stem cells using magnetic nanoparticles. Wiley Interdiscip. Rev. Nanomed. Nanobiotechnol. 3, 343-355. doi: 10.1002/wnan.140

Darsalia, V., Kallur, T., and Kokaia, Z. (2007). Survival, migration and neuronal differentiation of human fetal striatal and cortical neural stem cells grafted in stroke-damaged rat striatum. Eur. J. Neurosci. 26, 605-614. doi: 10.1111/j.14609568.2007.05702.x

Díez-Tejedor, E., Gutiérrez-Fernández, M., Martínez-Sánchez, P., RodríguezFrutos, B., Ruiz-Ares, G., Lara, M. L., et al. (2014). Reparative therapy for acute ischemic stroke with allogeneic mesenchymal stem cells from adipose tissue: a safety assessment: a phase II randomized, double-blind, placebo-controlled, single-center, pilot clinical trial. J. Stroke Cerebrovasc. Dis. 23, 2694-2700. doi: 10.1016/j.jstrokecerebrovasdis.2014.06.011

Emanueli, C., Schratzberger, P., Kirchmair, R., and Madeddu, P. (2003). Paracrine control of vascularization, and neurogenesis by neurotrophins. Br. J. Pharmacol. 140, 614-619. doi: 10.1038/sj.bjp.0705458

Feng, Y., Tian, G. P., Li, L., and Zhou, J. (2014). Effect of human umbilical cord blood-derived mesenchymal stem cells in the treatment of cerebral infarction. Pract. J. Cardiac. Cereb. Pneumal. Vasc. Dis. 22, 28-30.

Fernández-Susavila, H., Bugallo-Casal, A., Castillo, J., and Campos, F. (2019). Adult stem cells and induced pluripotent stem cells for stroke treatment. Front. Neurol. 10:908. doi: 10.3389/fneur.2019.00908

Fong, C. Y., Gauthaman, K., and Bongso, A. (2010). Teratomas from pluripotent stem cells: a clinical hurdle. J. Cell Biochem. 111, 769-781. doi: 10.1002/jcb. 22775

Ghosh, Z., Huang, M., Hu, S., Wilson, K. D., Dey, D., and Wu, J. C. (2011). Dissecting the oncogenic and tumorigenic potential of differentiated human induced pluripotent stem cells and human embryonic stem cells. Cancer Res. 71, 5030-5039. doi: 10.1158/0008-5472.CAN-10-4402

Hu, Q., Cao, M. Y., Li, R. F., Jiang, H. W., and Ge, L. T. (2013). Safety and efficacy on the treatment of cerebral infarction with umbilical cord mesenchymal stem cells. Med. J. Wuhan Univ. 34, 57-70.

Israel, M. A., Yuan, S. H., Bardy, C., Reyna, S. M., Mu, Y., Herrera, C., et al. (2012). Probing sporadic and familial Alzheimer's disease using induced pluripotent stem cells. Nature 482, 216-220. doi: 10.1038/nature10821

Jeyakumar, M., Lee, J. P., Sibson, N. R., Lowe, J. P., Stuckey, D. J., Tester, K., et al. (2009). Neural stem cell transplantation benefits a monogenic neurometabolic disorder during the symptomatic phase of disease. Stem Cells 27, 2362-2370. doi: $10.1002 /$ stem. 163

Jung, Y. L., Sang, I. P., Ji, H. O., Seong, M. K., Chang, H. J., Jin, A. J., et al. (2008). Brain-derived neurotrophic factor stimulates the neural differentiation of human umbilical cord blood-derived mesenchymal stem cells and survival of differentiated cells through MAPK/ERK and PI3K/Akt-dependent signaling pathways. J. Neurosci. Res. 86, 2168-2178. doi: 10.1002/jnr.21669

Kawai, H., Yamashita, T., Ohta, Y., Deguchi, K., Nagotani, S., Zhang, X., et al. (2010). Tridermal tumorigenesis of induced pluripotent stem cells transplanted in ischemic brain. J. Cereb. Blood Flow Metab. 30, 1487-1493. doi: 10.1038/ jcbfm.2010.32
Khalili, M. A., Anvari, M., Hekmati-Moghadam, S. H., Sadeghian-Nodoushan, F., Fesahat, F., and Miresmaeili, S. M. (2012). Therapeutic benefit of intravenous transplantation of mesenchymal stem cells after experimental subarachnoid hemorrhage in rats. J. Stroke Cerebrovasc. Dis. 21, 445-451. doi: 10.1016/j. jstrokecerebrovasdis.2010.10.005

Laskowitz, D. T., Bennett, E. R., Durham, R. J., Volpi, J. J., Wiese, J. R., Frankel, M., et al. (2018). Allogeneic umbilical cord blood infusion for adults with ischemic stroke: clinical outcomes from a phase 1 SAFETY STUDY. Stem Cells Transl. Med. 7, 521-529. doi: 10.1002/sctm.18-0008

Laso-García, F., Diekhorst, L., Gómez-De Frutos, M. C., Otero-Ortega, L., Fuentes, B., Ruiz-Ares, G., et al. (2019). Cell-based therapies for stroke: promising solution or dead end? Mesenchymal stem cells and comorbidities in preclinical stroke research. Front. Neurol. 10:332. doi: 10.3389/fneur.2019. 00332

Lee, H. J., Lim, I. J., Lee, M. C., and Kim, S. U. (2010). Human neural stem cells genetically modified to overexpress brain-derived neurotrophic factor promote functional recovery and neuroprotection in a mouse stroke model. J. Neurosci. Res. 88, 3282-3294. doi: 10.1002/jnr.22474

Lee, J. S., Hong, J. M., Moon, G. J., Lee, P. H., Ahn, Y. H., Bang, O. Y., et al. (2010). A long-term follow-up study of intravenous autologous mesenchymal stem cell transplantation in patients with ischemic stroke. Stem Cells 28, 1099-1106. doi: 10.1002/stem.430

Lee, J. P., Jeyakumar, M., Gonzalez, R., Takahashi, H., Lee, P. J., Baek, R. C., et al. (2007). Stem cells act through multiple mechanisms to benefit mice with neurodegenerative metabolic disease. Nat. Med. 13, 439-447. doi: 10.1038/ $\mathrm{nm} 1548$

Li, Y., Chen, J., Wang, L., Lu, M., and Chopp, M. (2001). Treatment of stroke in rat with intracarotid administration of marrow stromal cells. Neurology 56, 1666-1672. doi: 10.1212/WNL.56.12.1666

Li, Y., Chopp, M., Chen, J., Wang, L., Gautam, S. C., Xu, Y. X., et al. (2000). Intrastriatal transplantation of bone marrow nonhematopoietic cells improves functional recovery after stroke in adult mice. J. Cereb. Blood Flow Metab. 20, 1311-1319. doi: 10.1097/00004647-200009000-00006

Ma, F. W., Deng, Q. F., Zhou, X., Gong, X. J., Zhao, Y., Chen, H. G., et al. (2016). The tissue distribution and urinary excretion study of gallic acid and protocatechuic acid after oral administration of Polygonum capitatum extract in rats. Molecules 21:399. doi: 10.3390/molecules210 40399

Mays, R. W., Borlongan, C. V., Yasuhara, T., Hara, K., Maki, M., Carroll, J. E., et al. (2010). Development of an allogeneic adherent stem cell therapy for treatment of ischemic stroke*. J. Exp. Stroke Transl. Med. 3, 34-46. doi: 10.6030/1939067X-3.1.34

Levy, M. L., Crawford, J. R., Dib, N., Verkh, L., Tankovich, N., and Cramer, S. C. (2019). Phase I/II study of safety and preliminary efficacy of intravenous allogeneic mesenchymal stem cells in chronic stroke. Stroke 50, 2835-2841. doi: 10.1161/STROKEAHA.119.026318

Moniche, F., Gonzalez, A., Gonzalez-Marcos, J. R., Carmona, M., Piñero, P., Espigado, I., et al. (2012). Intra-arterial bone marrow mononuclear cells in ischemic stroke: a pilot clinical trial. Stroke 43, 2242-2244. doi: 10.1161/ STROKEAHA.112.659409

Moore, T. J., and Abrahamse, H. (2014). Neuronal differentiation of adipose derived stem cells: progress so far. Int. J. Photoenerg. 2014, 1-8. doi: 10.1155/ 2014/827540

Nagai, N., Kawao, N., Okada, K., Okumoto, K., Teramura, T., Ueshima, S., et al. (2010). Systemic transplantation of embryonic stem cells accelerates brain lesion decrease and angiogenesis. Neuroreport 21, 575-579. doi: 10.1097/WNR. 0b013e32833a7d2c

Nandy, S. B., Mohanty, S., Singh, M., Behari, M., and Airan, B. (2014). Fibroblast Growth Factor-2 alone as an efficient inducer for differentiation of human bone marrow mesenchymal stem cells into dopaminergic neurons. J. Biomed. Sci. 21:83. doi: 10.1186/s12929-014-0083-1

Oki, K., Tatarishvili, J., Wood, J., Koch, P., Wattananit, S., Mine, Y., et al. (2012). Human-induced pluripotent stem cells form functional neurons and improve recovery after grafting in stroke-damaged brain. Stem Cells 30, 1120-1133. doi: 10.1002/stem.1104

Otero, L., Zurita, M., Bonilla, C., Aguayo, C., Rico, M. A., Rodríguez, A., et al. (2012). Allogeneic bone marrow stromal cell transplantation after cerebral hemorrhage achieves cell transdifferentiation and modulates endogenous 
neurogenesis. Cytotherapy 14, 34-44. doi: $10.3109 / 14653249.2011 .60$ 8349

Ourednik, J., Ourednik, V., Lynch, W. P., Schachner, M., and Snyder, E. Y. (2002). Neural stem cells display an inherent mechanism for rescuing dysfunctional neurons. Nat. Biotechnol. 20, 1103-1110. doi: 10.1038/nbt750

Polezhaev, L. V., and Alexandrova, M. A. (1984). Transplantation of embryonic brain tissue into the brain of adult rats after hypoxic hypoxia. J. Hirnforsch. 25, 99-106.

Polezhaev, L. V., Alexandrova, M. A., Vitvitsky, V. N., Girman, S. V., and Golovina, I. L. (1985). Morphological, biochemical and physiological changes in brain nervous tissue of adult intact and hypoxia-subjected rats after transplantation of embryonic nervous tissue. J. Hirnforsch 26, 281-289.

Prasad, K., Sharma, A., Garg, A., Mohanty, S., Bhatnagar, S., Johri, S., et al. (2014). Intravenous autologous bone marrow mononuclear stem cell therapy for ischemic stroke: a multicentric, randomized trial. Stroke 45, 3618-3624. doi: 10.1161/STROKEAHA.114.007028

Ra, J. C., Shin, I. S., Kim, S. H., Kang, S. K., Kang, B. C., Lee, H. Y., et al. (2011). Safety of intravenous infusion of human adipose tissue-derived mesenchymal stem cells in animals and humans. Stem Cells Dev. 20, 1297-1308. doi: 10.1089/ scd.2010.0466

Redmond, D. E., Bjugstad, K. B., Teng, Y. D., Ourednik, V., Ourednik, J., Wakeman, D. R., et al. (2007). Behavioral improvement in a primate Parkinson's model is associated with multiple homeostatic effects of human neural stem cells. Proc. Natl. Acad. Sci. U.S.A. 104, 12175-12180. doi: 10.1073/pnas. 0704091104

Rodríguez-Frutos, B., Otero-Ortega, L., Gutiérrez-Fernández, M., Fuentes, B., Ramos-Cejudo, J., and Díez-Tejedor, E. (2016). Stem cell therapy and administration routes after stroke. Transl. Stroke Res. 7, 378-387. doi: 10.1007/ s12975-016-0482-6

Russell, A. L., Lefavor, R., Durand, N., Glover, L., and Zubair, A. C. (2018). Modifiers of mesenchymal stem cell quantity and quality. Transfusion 58, 1434-1440. doi: 10.1111/trf.14597

Ryu, S., Lee, S. H., Kim, S. U., and Yoon, B. W. (2016). Human neural stem cells promote proliferation of endogenous neural stem cells and enhance angiogenesis in ischemic rat brain. Neural. Regen. Res. 11, 298-304. doi: 10. 4103/1673-5374.177739

Shen, L. H., Li, Y., Chen, J., Zacharek, A., Gao, Q., Kapke, A., et al. (2007). Therapeutic benefit of bone marrow stromal cells administered 1 month after stroke. J. Cereb. Blood Flow Metab. 27, 6-13. doi: 10.1038/sj.jcbfm.96 00311

Shyu, W. C., Lin, S. Z., Chiang, M. F., Su, C. Y., and Li, H. (2006). Intracerebral peripheral blood stem cell $(\mathrm{CD} 34+)$ implantation induces neuroplasticity by enhancing $\beta 1$ integrin-mediated angiogenesis in chronic stroke rats. J. Neurosci. 26, 3444-3453. doi: 10.1523/JNEUROSCI.5165-05. 2006

Singh, M., Kakkar, A., Sharma, R., Kharbanda, O. P., Monga, N., Kumar, M., et al. (2017). Synergistic Effect of BDNF and FGF2 in Efficient Generation of Functional Dopaminergic Neurons from human Mesenchymal Stem Cells. Sci. Rep. 7:10378. doi: 10.1038/s41598-01711028-z

Smith, E. J., Stroemer, R. P., Gorenkova, N., Nakajima, M., Crum, W. R., Tang, E., et al. (2012). Implantation site and lesion topology determine efficacy of a human neural stem cell line in a rat model of chronic stroke. Stem Cells 30, 785-796. doi: 10.1002/stem.1024

Song, M., Kim, Y. J., Kim, Y. H., Roh, J., Kim, E. C., Lee, H. J., et al. (2015). Long-term effects of magnetically targeted ferumoxide-labeled human neural stem cells in focal cerebral ischemia. Cell Transplant 24, 183-190. doi: 10.3727/ 096368913 X675755

Steven, C. C. (2008). Repairing the human brain after stroke: I. Mechanisms of spontaneous recovery. Ann. Neurol. 63, 272-287. doi: 10.1002/ana. 21393

Tae-Hoon, L., and Yoon-Seok, L. (2012). Transplantation of mouse embryonic stem cell after middle cerebral artery occlusion. Acta Cir. Bras. 27, 333-339. doi: 10.1590/s0102-86502012000400009

Taguchi, A., Soma, T., Tanaka, H., Kanda, T., Nishimura, H., Yoshikawa, H., et al. (2004). Administration of CD34+ cells after stroke enhances neurogenesis via angiogenesis in a mouse model. J. Clin. Invest. 114, 330-338. doi: 10.1172/ JCI200420622
Takahashi, K., and Yamanaka, S. (2006). Induction of Pluripotent Stem Cells from Mouse Embryonic and Adult Fibroblast Cultures by Defined Factors. Cell 126, 663-676. doi: 10.1016/j.cell.2006.07.024

Takahashi, K., Yasuhara, T., Shingo, T., Muraoka, K., Kameda, M., Takeuchi, A., et al. (2008). Embryonic neural stem cells transplanted in middle cerebral artery occlusion model of rats demonstrated potent therapeutic effects, compared to adult neural stem cells. Brain Res. 1234, 172-182. doi: 10.1016/j.brainres.2008. 07.086

Thomson, J. A. (1998). Embryonic stem cell lines derived from human blastocysts. Science 282, 1145-1147. doi: 10.1126/science.282.5391.1145

Thwaites, J. W., Reebye, V., Mintz, P., Levicar, N., and Habib, N. (2012). Cellular replacement and regenerative medicine therapies in ischemic stroke. Regen. Med. 7, 387-395. doi: 10.2217/rme.12.2

Toda, H., Takahashi, J., Iwakami, N., Kimura, T., Hoki, S., Mozumi-Kitamura, K., et al. (2001). Grafting neural stem cells improved the impaired spatial recognition in ischemic rats. Neurosci. Lett. 316, 9-12. doi: 10.1016/S03043940(01)02331-X

Turnbull, M. T., Zubair, A. C., Meschia, J. F., and Freeman, W. D. (2019). Mesenchymal stem cells for hemorrhagic stroke: status of preclinical and clinical research. NPJ Regen. Med. 4:10. doi: 10.1038/s41536-019-0073-8

Uccelli, A., Moretta, L., and Pistoia, V. (2008). Mesenchymal stem cells in health and disease. Nat. Rev. Immunol. 8, 726-736. doi: 10.1038/nri2395

Vahidy, F. S., Haque, M. E., Rahbar, M. H., Zhu, H., Rowan, P., Aisiku, I. P., et al. (2019). Intravenous bone marrow mononuclear cells for acute ischemic stroke: safety, feasibility, and effect size from a phase i clinical trial. Stem Cells 37, 1481-1491. doi: 10.1002/stem.3080

Vaquero, J., Otero, L., Bonilla, C., Aguayo, C., Rico, M. A., Rodriguez, A., et al. (2013). Cell therapy with bone marrow stromal cells after intracerebral hemorrhage: impact of platelet-rich plasma scaffolds. Cytotherapy 15, 33-43. doi: 10.1016/j.jcyt.2012.10.005

Wichterle, H., Lieberam, I., Porter, J. A., and Jessell, T. M. (2002). Directed differentiation of embryonic stem cells into motor neurons. Cell 110, 385-397. doi: 10.1016/S0092-8674(02)00835-8

Xie, J., Wang, B., Wang, L., Dong, F., Bai, G., and Liu, Y. (2016). Intracerebral and intravenous transplantation represents a favorable approach for application of human umbilical cord mesenchymal stromal cells in intracerebral hemorrhage rats. Med. Sci. Monit. 22, 3552-3561. doi: 10.12659/MSM.90 0512

Xin, H., Li, Y., Cui, Y., Yang, J. J., Zhang, Z. G., and Chopp, M. (2013). Systemic administration of exosomes released from mesenchymal stromal cells promote functional recovery and neurovascular plasticity after stroke in rats. J. Cereb. Blood Flow Metab. 33, 1711-1715. doi: 10.1038/jcbfm.2013.152

Xiong, X., Gu, L., Wang, Y., Luo, Y., Zhang, H., Lee, J., et al. (2016). Glycyrrhizin protects against focal cerebral ischemia via inhibition of $\mathrm{T}$ cell activity and HMGB1-mediated mechanisms. J. Neuroinflam. 13:241. doi: 10.1186/s12974016-0705-5

Yang, K. L., Lee, J. T., Pang, C. Y., Lee, T. Y., Chen, S. P., Liew, H. K., et al. (2012). Human adipose-derived stem cells for the treatment of intracerebral hemorrhage in rats via femoral intravenous injection. Cell Mol. Biol. Lett. 17, 376-392. doi: 10.2478/s11658-012-0016-5

Yao, R. Q., Qi, D. S., Yu, H. L., Liu, J., Yang, L. H., and Wu, X. X. (2012). Quercetin attenuates cell apoptosis in focal cerebral ischemia rat brain via activation of BDNF-TrkB-PI3K/Akt signaling pathway. Neurochem. Res. 37, 2777-2786. doi: 10.1007/s11064-012-0871-5

Yu, S. P., Wei, Z., and Wei, L. (2013). Preconditioning strategy in stem cell transplantation therapy. Transl. Stroke Res. 4, 76-88. doi: 10.1007/s12975-0120251-0

Zhang, B., Yin, Y., Lai, R. C., Tan, S. S., Choo, A. B. H., and Lim, S. K. (2014). Mesenchymal stem cells secrete immunologically active exosomes. Stem Cells Dev. 23, 1233-1244. doi: 10.1089/scd.2013.0479

Zhang, G., Li, Y., Reuss, J. L., Liu, N., Wu, C., Li, J., et al. (2019). Stable intracerebral transplantation of neural stem cells for the treatment of paralysis due to ischemic stroke. Stem Cells Transl. Med. 8, 999-1007. doi: 10.1002/sctm.180220

Zhang, H., Huang, Z., Xu, Y., and Zhang, S. (2006). Differentiation and neurological benefit of the mesenchymal stem cells transplanted into the rat brain following intracerebral hemorrhage. Neurol. Res. 28, 104-112. doi: 10. $1179 / 016164106 \times 91960$ 
Zhang, Q., Shang, X., Hao, M., Zheng, M., Li, Y., Liang, Z., et al. (2015). Effects of human umbilical cord mesenchymal stem cell transplantation combined with minimally invasive hematoma aspiration on intracerebral hemorrhage in rats. Am. J. Transl. Res. 7, 2176-2186.

Zhang, Y., Chopp, M., Meng, Y., Katakowski, M., Xin, H., Mahmood, A., et al. (2015). Effect of exosomes derived from multipluripotent mesenchymal stromal cells on functional recovery and neurovascular plasticity in rats after traumatic brain injury. J. Neurosurg. 122, 856-867. doi: 10.3171/2014.11.JNS 14770

Zheng, H., Zhang, B., Chhatbar, P. Y., Dong, Y., Alawieh, A., Lowe, F., et al. (2018). Mesenchymal stem cell therapy in stroke: a systematic review of literature in pre-clinical and clinical research. Cell Transplant 27, 1723-1730. doi: 10.1177/ 0963689718806846

Zhu, J. R., Lu, H. D., Guo, C., Fang, W. R., Zhao, H. D., Zhou, J. S., et al. (2018). Berberine attenuates ischemia-reperfusion injury through inhibiting HMGB1 release and NF- $\mathrm{B}$ nuclear translocation. Acta Pharmacol. Sin. 39, 1706-1715. doi: 10.1038/s41401-0180160-1

Conflict of Interest: The authors declare that the research was conducted in the absence of any commercial or financial relationships that could be construed as a potential conflict of interest.

Copyright (c) 2020 Singh, Pandey, Bhasin, Padma and Mohanty. This is an openaccess article distributed under the terms of the Creative Commons Attribution License (CC BY). The use, distribution or reproduction in other forums is permitted, provided the original author(s) and the copyright owner(s) are credited and that the original publication in this journal is cited, in accordance with accepted academic practice. No use, distribution or reproduction is permitted which does not comply with these terms. 